\title{
Tuberibacillus calidus gen. nov., sp. nov., isolated from a compost pile and reclassification of Bacillus naganoensis Tomimura et al. 1990 as Pullulanibacillus naganoensis gen. nov., comb. nov. and Bacillus laevolacticus Andersch et al. 1994 as Sporolactobacillus laevolacticus comb.
} nov.

Correspondence
Akira Nakamura
a-nak@agbi.tsukuba.ac.jp

\author{
Kouta Hatayama, ${ }^{1}$ Hirofumi Shoun, ${ }^{2}$ Yasuichi Ueda ${ }^{3}$ and Akira Nakamura ${ }^{1}$ \\ 'Division of Integrative Environmental Sciences, Graduate School of Life and Environmental \\ Sciences, University of Tsukuba, Tennodai 1-1-1, Tsukuba, Ibaraki 305-8572, Japan \\ ${ }^{2}$ Department of Biotechnology, Graduate School of Agricultural and Life Sciences, The \\ University of Tokyo, Yayoi 1-1-1, Bunkyo-ku, Tokyo 113-8657, Japan \\ ${ }^{3}$ Institute of Hyperthermophiles, Motobu-Noge Hospital, Aza-Ohama 880-1, Motobu, Okinawa \\ 905-0212, Japan
}

\footnotetext{
Abbreviation: ITS, internal transcribed spacer.

The GenBank/EMBL/DDBJ accession numbers for the 16S rRNA gene sequences of Tuberibacillus calidus $607^{\top}$ and $606 \mathrm{~b}$ are AB231786 and AB231785, respectively. The accession numbers for the nucleotide sequences of the 16S-23S ITS regions of the Tuberibacillus, Pullulanibacillus and Sporolactobacillus strains determined in this work are AB231787-AB231797.

An additional phylogenetic tree, phase-contrast microscope images of cells of Tuberibacillus calidus sp. nov. and a table detailing major cellular fatty acids for the novel isolates and related recognized species are available as supplementary material in IJSEM Online.
}

The genus Bacillus consists of many species which display a variety of physiological and chemotaxonomic characteristics (Claus \& Berkeley, 1986). Recent studies have shown that this genus is in fact made up of heterogeneous genera and several new genera have been established from this genus (Niimura et al., 1990; Wisotzkey et al., 1992; Ash et al., 1993; Shida et al., 1996; Heyndrickx et al., 1998; Wainø et al., 1999; Schlesner et al., 2001; Fortina et al., 2001; Nazina et al., 2001; Yoon et al., 2001). However, it has been noted that are still several species of the genus Bacillus which need to be reclassified into other genera (Xu \& Côté, 2003). 
In our study of the microbial flora associated with the hyperthermal composting process in Japan, several mesophilic and thermophilic strains have been previously isolated and characterized (Hatayama et al., 2005a, b). In this process, organic wastes were subjected to a rapid composting step at a high temperature using a hyperthermal composting machine followed by a further piling step in the atmosphere. In this latter step, the temperature of the compost piles was kept at approximately $60^{\circ} \mathrm{C}$ for several weeks by the heat generated metabolically by the micro-organisms growing in the compost piles, as is the case for general composting (Fogarty \& Tuovinen, 1991; Williams et al., 1992). After the easily metabolized organic compounds in the piles had been thoroughly utilized by the micro-organisms, the temperature of the piles decreased to the ambient temperature, indicating the maturation of the compost piles. We assumed that the microbial flora in the piles changed as the composting process progressed, as in other composting processes (Fogarty \& Tuovinen, 1991; Ishii et al., 2000). We also assumed that when the easily metabolized organic compounds became scarce in the piles, such as during the later step in this process, the populations of some microorganisms that utilize the corpses of previously dominant microbes might rise. To isolate these micro-organisms from the samples, we developed a medium containing microbial corpses as the sole nutrient source. Two thermophilic bacteria, $607^{\mathrm{T}}$ and $606 \mathrm{~b}$, growing at around $60^{\circ} \mathrm{C}$, were isolated using this medium. From our phylogenetic analyses, based on 16S rRNA gene sequences and the sequences of the internal transcribed spacer (ITS) regions between the $16 \mathrm{~S}$ and $23 \mathrm{~S}$ rRNA genes, as well as chemotaxonomic and physiological characterizations of strains $607^{\mathrm{T}}$ and 606b, we propose that the strains represent a new genus and novel species, Tuberibacillus calidus gen. nov., sp. nov.

Furthermore, during the above-mentioned analyses, we found that Bacillus naganoensis and Bacillus laevolacticus should be reclassified into other genera than the genus Bacillus. B. naganoensis was isolated as a producer of pullulanase and proposed by Tomimura et al. (1990). However, this species was established mainly on the basis of the results of physiological characterization and not analysed according to its phylogenetic position based on $16 \mathrm{~S}$ rRNA gene sequence. Although Goto et al. (2000) determined the $16 \mathrm{~S}$ rRNA gene sequence for B. naganoensis, there has been no discussion on the taxonomic position of this species. B. laevolacticus, originally described by Nakayama \& Yanoshi (1967), was proposed by Andersch et al. (1994). At the time of this proposal, the close relationship of this species to the genus Sporolactobacillus was discussed, but it was nonetheless classified in the genus Bacillus. On the basis of the data described here, we propose the reclassification of $B$. naganoensis as Pullulanibacillus naganoensis gen. nov., comb. nov. and B. laevolacticus as Sporolactobacillus laevolacticus comb. nov.

To isolate microbes that utilize the corpses of other microbes during the later piling step of the hyperthermal composting process, we used plates comprising microbial corpses, termed MC agar. To make these plates and to isolate such microbes, we used a sample from the compost pile obtained when the temperature of the pile was beginning to decrease, since this sample had the potential to contain various microbes related to the succession of the microbial flora. Microbes originating from this sample were cultured in Luria-Bertani (LB) medium at $37^{\circ} \mathrm{C}$ overnight and the cells were collected by centrifugation. The cells were suspended in an equal volume of distilled water and sterilized by autoclaving at $121^{\circ} \mathrm{C}$ for $20 \mathrm{~min}$, after the addition of $1.5 \%$ agar. Using the $\mathrm{MC}$ agar made in this way, several micro-organisms growing at $60{ }^{\circ} \mathrm{C}$ were isolated from the same sample.

To determine the rough phylogenetic positions of the novel isolates, partial sequences of their 16S rRNA genes (approximately $500 \mathrm{bp}$ ) were analysed. DNA extraction from colonized cells was performed using the method of Zhu et al. (1993). PCR amplification and analysis of the partial 16S rRNA gene sequences were performed as previously described (Hatayama et al., 2005a) using Eubac27F (DeLong, 1992) and 518R (Ogino et al., 2001) primers. The results of a similarity search using BLASTN (Altschul et al., 1997) revealed that most of the isolates were closely related to Bacillus smithii (>99.6\% similarity; data not shown). However, the sequences of two isolates, designated $607^{\mathrm{T}}$ and $606 \mathrm{~b}$, showed high similarity $(99 \cdot 8$ and $100 \%$, respectively) to that of uncultured bacterial clone F2-7 isolated from a hydrogen sulfide and methanol biofilter (GenBank accession no. AY096130), but did not show any close relationships to recognized species.

To determine the phylogenetic position of strains $607^{\mathrm{T}}$ and $606 \mathrm{~b}$ in more detail, PCR amplification of their 16S rRNA genes ( $>95 \%$ of their full length) was performed with Eubac27F and 1492R (DeLong, 1992) primers. Sequencing and phylogenetic analyses were performed as previously described (Hatayama et al., 2005a). The 16S rRNA gene sequences were aligned at positions 28 to 1490 [Escherichia coli numbering system (Brosius et al., 1978)] using the CLUSTAL_X software package (Thompson et al., 1997). Distance values were calculated using the method described by Kimura (1980). These values were then used in CLUSTAL_X to construct a phylogenetic tree by the neighbour-joining method with bootstrap values based on 1000 replications. A maximum-likelihood analysis was performed in DNAML with bootstrap values based on 100 replications using the SEQBOOT and CONSENSE programs of the PHYLIP package, version 3.65 (Felsenstein, 2005). The results were visualized using TREEVIEW software (Page, 1996). The 16S rRNA gene sequences of strains $607^{\mathrm{T}}$ and 606b were almost identical (99.9\% similarity) and homology searches in BLASTN and FASTA (Pearson, 2000) revealed that the closest recognized species to these strains was Bacillus naganoensis $(94 \cdot 0-94 \cdot 1 \%$ similarity). The novel strains showed relatively low 16S rRNA gene sequence similarities to members of the genera Bacillus (below 
$91 \cdot 9 \%)$ and Sporolactobacillus $(91 \cdot 0-92 \cdot 5 \%)$. In the phylogenetic tree built via the neighbour-joining method, strains $607^{\mathrm{T}}$ and 606b formed an independent lineage from that of B. naganoensis. These two lineages were not included in the clusters of the genus Sporolactobacillus or of the genus Bacillus and related genera (Fig. 1). Similar results were obtained in the phylogenetic tree generated via the maximum-likelihood method (data not shown). These phylogenetic trees also revealed that B. laevolacticus was not included in the cluster of the genus Bacillus, but was found in the cluster of the genus Sporolactobacillus (Fig. 1). However, Xu \& Côté (2003) reported that B. laevolacticus grouped with Virgibacillus pantothenticus on the basis of the results of phylogenetic analysis based on the nucleotide sequences of $3^{\prime}$-end of the $16 \mathrm{~S}$ rRNA gene (150 bp) and $5^{\prime}$ end of the 16S-23S rRNA gene ITS (16S-23S ITS) region (70 bp). In order to clarify the phylogenetic position of B. laevolacticus, PCR amplification, cloning and sequencing of $3^{\prime}$-end of the 16S rRNA gene and $5^{\prime}$-end of the 16S-23S ITS region were conducted for strains $607^{\mathrm{T}}$ and $606 \mathrm{~b}, B$. naganoensis, $B$. laevolacticus and members of the genus Sporolactobacillus according to the method of Xu \& Côté (2003) and a phylogenetic analysis was performed with the sequence data for members of related genera. Our phylogenetic tree, constructed via the neighbour-joining method, indicated that $B$. laevolacticus fell into the cluster of the genus Sporolactobacillus (see Supplementary Fig. S1 in IJSEM Online). We therefore propose that B. laevolacticus should be reclassified into the genus Sporolactobacillus. Moreover, this tree again indicated that strains $607^{\mathrm{T}}$ and $606 \mathrm{~b}$ and B. naganoensis belong to different lineages, separated from the clusters of the genera Bacillus and Sporolactobacillus. The phylogenetic analysis also showed that strains $607^{\mathrm{T}}$ and 606b were separated into two independent lineages. It is notable that this phylogeny reflects the differences in their nucleotide sequences at the $5^{\prime}$-end of the 16S-23S ITS region, rather than the $3^{\prime}$-end of the $16 \mathrm{~S}$ rRNA coding region (data not shown). These phylogenetic analyses strongly suggest that strains $607^{\mathrm{T}}$ and $606 \mathrm{~b}$ and $B$. naganoensis do not belong to the genera Bacillus or Sporolactobacillus and that the two novel strains and $B$. naganoensis should be classified into two different genera. Based on these observations, strains $607^{\mathrm{T}}$ and $606 \mathrm{~b}, B$. naganoensis DSM $10191^{\mathrm{T}}$ and B. laevolacticus DSM $442^{\mathrm{T}}$ were subjected to physiological and chemotaxonomic characterization using Sporolactobacillus kofuensis JCM $3419^{\mathrm{T}}$, Sporolactobacillus inulinus DSM $20348^{\mathrm{T}}$, Sporolactobacillus nakayamae subsp. nakayamae DSM $11696^{\mathrm{T}}$ and Sporolactobacillus terrae DSM $11697^{\mathrm{T}}$ as reference strains.

The MC agar plates initially used for the isolation of the novel strains were not suitable for the maintenance and characterization of strains $607^{\mathrm{T}}$ and 606b. A medium was selected in which strains $607^{\mathrm{T}}$ and 606b would grow well. Although strains $607^{\mathrm{T}}$ and 606b did not show any growth in LB medium, nutrient medium (nutrient broth; Difco) or GYP medium (Yanagida et al., 1997), they grew in CYC medium [33.4 g Czapek-Dox liquid medium, modified (Oxoid), $2.0 \mathrm{~g}$ Bacto yeast extract (Difco), 6.0 g Bacto vitamin assay Casamino acids (Difco), $1000 \mathrm{ml}$ distilled water, pH 7.2] (Lacey \& Cross, 1989) at $60{ }^{\circ} \mathrm{C}$ and this medium was used for further work. Colonies of strains $607^{\mathrm{T}}$ and $606 \mathrm{~b}$ were round, obscure-edged, translucent and cream in colour. The cells were Gram-positive rods (using Live BacLight Bacterial Gram Stain Kit; Invitrogen), 3-7 $\mu \mathrm{m}$ long and $0 \cdot 3-0 \cdot 5 \mu \mathrm{m}$ wide, non-motile and occurred singly or in chains. Strains $607^{\mathrm{T}}$ and 606 both formed oval endospores which were $0 \cdot 7-1 \cdot 0 \mu \mathrm{m}$ long and $0 \cdot 5-0 \cdot 7 \mu \mathrm{m}$ wide and located terminally within swollen sporangia (see Supplementary Fig. S2 in IJSEM Online). The widths of

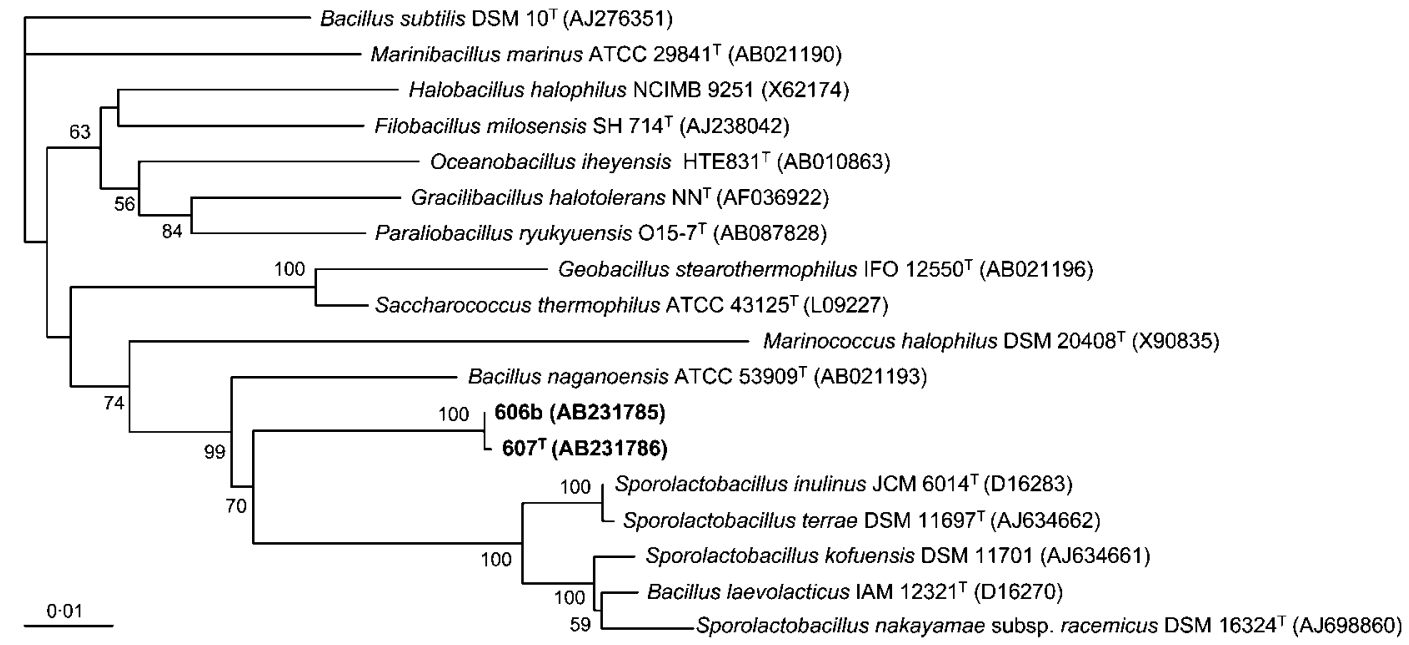

Fig. 1. Neighbour-joining phylogenetic tree based on the $16 \mathrm{~S}$ rRNA gene sequences of strains $607^{\top}$ and $606 \mathrm{~b}, B$. naganoensis, B. laevolacticus and recognized species of related genera. Bootstrap values are calculated from 1000 replications and values $>50 \%$ are shown at branch points. GenBank accession numbers are shown in parentheses. Bar, 0.01 substitutions per nucleotide position. 
the spores were greater than those of the cells. In CYC medium, growth of strains $607^{\mathrm{T}}$ and 606b was observed over a pH range of $5 \cdot 0-7 \cdot 0$ and over a temperature range of 40 to $60^{\circ} \mathrm{C}$, with optimal growth at between 50 and $55^{\circ} \mathrm{C}$.

To examine strains $607^{\mathrm{T}}$ and $606 \mathrm{~b}$ in more detail, their physiological characteristics were determined as described by Claus \& Berkeley (1986). Lactic acid production was tested using an F-kit (D-lactic acid L-lactic acid; Roche Diagnostics). There were several differences in physiological characteristics between the novel strains and the other reference strains (Table 1). Notably, a marked difference was seen in the growth temperature: strains $607^{\mathrm{T}}$ and $606 \mathrm{~b}$ grow at up to $60^{\circ} \mathrm{C}$ and can therefore be classified as thermophiles, whereas the reference strains, including the closest related species, B. naganoensis, are mesophiles.
Strains $607^{\mathrm{T}}$ and $606 \mathrm{~b}$ and B. naganoensis showed some features that distinguished them from species of the genus Sporolactobacillus and B. laevolacticus, such as having catalase activities and not producing lactic acid. Strains $607^{\mathrm{T}}$ and 606b could also be distinguished from $B$. naganoensis by the presence of oxidase activity, the $\mathrm{pH}$ range for growth and the hydrolysis of starch and casein. Several differences were also detected between strains $607^{\mathrm{T}}$ and $606 \mathrm{~b}$, such as nitrate reduction ability, acid production from xylose and tolerance of $\mathrm{NaCl}$. B. laevolacticus showed almost the same features as species of the genus Sporolactobacillus except for the hydrolysis of starch.

Chemotaxonomic characteristics and the DNA G+C content were determined as previously described (Hatayama et al., 2005b) using cells of strains $607^{\mathrm{T}}$ and

Table 1. Differential physiological and chemotaxonomic characteristics of strains $607^{\top}$ and $606 \mathrm{~b}, B$. naganoensis, B. laevolacticus and related recognized species

Taxa: $1,607^{\mathrm{T}} ; 2,606 \mathrm{~b} ; 3$, B. naganoensis (data from Tomimura et al., 1990, except for oxidase, cell-wall sugars, major menaquinone and major cellular fatty acids); 4, B. laevolacticus (data from Andersch et al., 1994, except for catalase and cell-wall sugars); 5, S. inulinus; 6, S. kofuensis; 7, S. nakayamae; 8, S. terrae. For taxa 5-8, data are from Yanagida et al. (1997), except for cell-wall sugars, hydrolysis and utilization of substrates and nitrate reduction. +, Positive reaction; -, negative reaction; ND, no data available. All strains contain menaquinone7 as the major isoprenoid quinone and are negative in tests for hydrolysis of tyrosine, utilization of citrate and propionate and phenylalanine deaminase activity.

\begin{tabular}{|c|c|c|c|c|c|c|c|c|}
\hline Characteristic & 1 & 2 & 3 & 4 & 5 & 6 & 7 & 8 \\
\hline Oxidase activity & + & + & - & - & - & - & - & - \\
\hline Lactic acid production & - & - & ND & + & + & + & + & + \\
\hline Growth temperature range $\left({ }^{\circ} \mathrm{C}\right)$ & $40-60$ & $40-60$ & $28-33$ & $15-40$ & $25-40$ & $25-40$ & $15-40$ & $15-40$ \\
\hline Hydrolysis of starch & - & - & + & + & - & - & - & - \\
\hline Hydrolysis of casein & + & + & - & - & - & - & - & - \\
\hline Nitrate reduction & + & - & - & - & - & - & - & - \\
\hline \multicolumn{9}{|l|}{ Acid production from: } \\
\hline Arabinose & + & + & + & - & - & - & - & - \\
\hline Galactose & - & - & + & + & + & + & + & + \\
\hline Glucose & - & - & + & - & + & + & + & + \\
\hline Mannose & - & - & - & + & - & - & + & - \\
\hline Rhamnose & - & - & + & + & - & - & + & - \\
\hline \multicolumn{9}{|l|}{ Predominant cellular fatty acids: $\dagger$} \\
\hline $\mathrm{C}_{16: 0}$ & - & - & - & - & ND & - & - & - \\
\hline iso- $\mathrm{C}_{16: 0}$ & - & - & + & - & ND & - & - & - \\
\hline anteiso- $\mathrm{C}_{15: 0}$ & - & - & - & + & ND & + & + & + \\
\hline anteiso- $\mathrm{C}_{17: 0}$ & + & + & - & + & ND & + & + & + \\
\hline DNA G $+C$ content $(\mathrm{mol} \%)$ & $46 \cdot 0$ & $47 \cdot 3$ & $45 \pm 2$ & $43-45$ & 47 & 43 & $43-47$ & $43-46$ \\
\hline
\end{tabular}

${ }^{*}$ A positive reaction was reported by Andersch et al. (1994).

$\dagger$ Major components consisting of about $50 \%$ of total cellular fatty acids are regarded as predominant cellular fatty acids in taxa $1-3$. 
606b, B. naganoensis and the other reference strains cultured in CYC medium at $55^{\circ} \mathrm{C}, \mathrm{CYC}$ medium ( $\mathrm{pH}$ was adjusted to $5 \cdot 0$ ) at $30^{\circ} \mathrm{C}$ and GYP medium at $30^{\circ} \mathrm{C}$, respectively. The cell-wall peptidoglycan of strains $607^{\mathrm{T}}$ and $606 \mathrm{~b}$ contained meso-diaminopimelic acid, alanine and glutamic acid as did that of the reference strains (data not shown). No sugars were detected in the cell walls of strains $607^{\mathrm{T}}$ and $606 \mathrm{~b}$, whereas those of the reference strains contained several sugars (Table 1). The predominant cellular fatty acid of strains $607^{\mathrm{T}}$ and 606b was anteiso- $\mathrm{C}_{17: 0}$, which differed from those of the reference strains (Table 1 and Supplementary Table S1). Strains $607^{\mathrm{T}}$ and $606 \mathrm{~b}$ and the reference strains contained menaquinone- 7 as the predominant component of isoprenoid quinone and menaquinone-5 as the minor component (above $10 \%$ peak area ratio). The DNA G $+\mathrm{C}$ contents of strains $607^{\mathrm{T}}$ and $606 \mathrm{~b}$ were $46 \cdot 0$ and $47 \cdot 3 \mathrm{~mol} \%$, respectively, which were almost the same as those of the reference strains.

Our phylogenetic analyses based on $16 \mathrm{~S}$ rRNA gene sequences and the nucleotide sequences of the 16S-23S ITS region (Fig. 1 and Supplementary Fig. S1) indicated that strains $607^{\mathrm{T}}$ and $606 \mathrm{~b}$ could be classified as representing a novel species in a new genus. The differences found in growth temperatures, cell-wall sugar composition, cellular fatty acids and other physiological characteristics between strains $607^{\mathrm{T}}$ and 606b and related genera also support this proposal (Table 1). Although strains $607^{\mathrm{T}}$ and $606 \mathrm{~b}$ showed differences in their nitrate reduction ability, acid production from xylose, tolerance of $\mathrm{NaCl}$ and in the nucleotide sequences of the 16S-23S ITS regions, DNA-DNA hybridization studies, using the method of Ezaki et al. (1989), indicated that the two strains belong to the same species (79-100\% DNA-DNA relatedness). On the basis of these results, we propose that strains $607^{\mathrm{T}}$ and $606 \mathrm{~b}$ be classified as Tuberibacillus calidus gen. nov., sp. nov., with strain $607^{\mathrm{T}}$ as the type strain.

On the basis of 16S rRNA gene sequence similarity $(<92.9 \%$, data not shown) and phylogenetic analyses (Fig. 1 and Supplementary Fig. S1), B. naganoensis showed a low relationship to the genera Bacillus and Sporolactobacillus. The cellular fatty acid profile of $B$. naganoensis also differed from those of related species (Table 1 and Supplementary Table S1). B. laevolacticus was included in the cluster of the genus Sporolactobacillus in both phylogenetic trees (Fig. 1 and Supplementary Fig. S1) and its physiological and chemotaxonomic characteristics mostly agreed with those of other species of this genus (Table 1). Therefore, we also propose that Bacillus naganoensis (Tomimura et al., 1990) is reclassified as Pullulanibacillus naganoensis gen. nov., comb. nov. and Bacillus laevolacticus is reclassified as Sporolactobacillus laevolacticus comb. nov.

\section{Description of Tuberibacillus gen. nov.}

Tuberibacillus (Tu.be.ri.ba.cil'lus. L. neut. n. tuber swelling; L. masc. n. bacillus a small staff; N.L. masc. n. Tuberibacillus a small staff with a swelling).
Cells are aerobic, thermophilic, Gram-positive rods $(3-7 \times 0 \cdot 3-0.5 \mu \mathrm{m})$, occur singly or in chains and are non-motile. Oval endospores $(0 \cdot 7-1 \cdot 0 \times 0.5-0.7 \mu \mathrm{m})$ are formed terminally within swollen sporangia. Catalase- and oxidase-positive. The cell-wall peptidoglycan contains mesodiaminopimelic acid, alanine and glutamic acid, but no sugars. The major menaquinone is MK-7. The predominant fatty acid is anteiso- $\mathrm{C}_{17: 0}$. The DNA G $+\mathrm{C}$ content is $46 \cdot 0-47 \cdot 3 \mathrm{~mol} \%$. The type species is Tuberibacillus calidus.

\section{Description of Tuberibacillus calidus sp. nov.}

Tuberibacillus calidus (ca.li'dus. L. adj. calidus hot, due to their growth temperature).

Displays the following properties in addition to those given in the genus description. Growth is observed on CYC medium [33.4 g Czapek-Dox liquid medium, modified (Oxoid), $2.0 \mathrm{~g}$ Bacto yeast extract (Difco), 6.0 g Bacto vitamin assay Casamino acids (Difco), $1000 \mathrm{ml}$ distilled water, $\mathrm{pH}$ 7·2] under aerobic and thermophilic conditions. Colonies are round, obscure-edged, translucent and cream in colour. Growth occurs at a $\mathrm{pH}$ range of $5 \cdot 0-7 \cdot 0$ and at $40-60{ }^{\circ} \mathrm{C}$ (with an optimum temperature of $50-55^{\circ} \mathrm{C}$ ) and $0-2$ or $0-4 \% \mathrm{NaCl}$. Positive reactions are observed for catalase and oxidase activities and for the hydrolysis of casein. Negative reactions are observed for the deamination of phenylalanine, hydrolysis of starch and tyrosine, utilization of citrate and propionate and the production of lactic acid. Acid is produced from glucose and arabinose, but not from lactose. Nitrate reduction and acid production from xylose are dependent on the strain. DNA G $+\mathrm{C}$ content is $46 \cdot 0-47 \cdot 3 \mathrm{~mol} \%$. When grown in CYC medium at $55^{\circ} \mathrm{C}$, the predominant cellular fatty acid is anteiso- $\mathrm{C}_{17: 0}$ with iso$\mathrm{C}_{17: 0}$ and iso- $\mathrm{C}_{16: 0}$ as minor components.

The type strain, strain $607^{\mathrm{T}}\left(=\mathrm{JCM} 13397^{\mathrm{T}}=\mathrm{DSM} 17572^{\mathrm{T}}\right)$, was isolated from a compost pile undergoing a hyperthermal composting process in Okinawa Prefecture, Japan. Strain $606 \mathrm{~b}$ is a reference strain.

\section{Description of Pullulanibacillus gen. nov.}

Pullulanibacillus (Pul.lu.la.ni.ba.cil'lus. N.L. n. pullulanum pullulan; L. masc. n. bacillus a small staff; N.L. masc. n. Pullulanibacillus a small staff hydrolysing pullulan).

Cells are aerobic, non-motile, Gram-positive rods $(0 \cdot 5-1 \cdot 0 \times 2 \cdot 1-10 \cdot 0 \mu \mathrm{m})$ with rounded or square ends and occur singly or in chains. Endospores are oval and cause swelling of the sporangia. Mesophilic and moderately acidophilic. Catalase-positive. Tests for reduction of nitrate to nitrite and nitrite to $\mathrm{NO}_{2}$ are negative. When grown in nutrient broth containing $1 \%$ starch, the major fatty acid is iso- $\mathrm{C}_{16: 0}$. The DNA $\mathrm{G}+\mathrm{C}$ content is $45 \pm 2 \mathrm{~mol} \%$. Additional characteristics found in this study are as follows: oxidase-negative, cell-wall peptidoglycan contains mesodiaminopimelic acid, alanine, glutamic acid, galactose, glucose and rhamnose and menaquinone- 7 and menaquinone- 5 are the major and minor isoprenoid quinones, 
respectively. When grown in $\mathrm{CYC}(\mathrm{pH} 5 \cdot 0)$ medium, the predominant cellular fatty acids are $\mathrm{C}_{16: 0}$ and iso- $\mathrm{C}_{16: 0}$, with

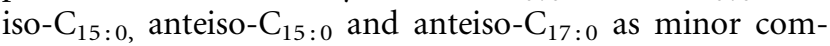
ponents. The type species is Pullulanibacillus naganoensis.

\section{Description of Pullulanibacillus naganoensis comb. nov.}

Pullulanibacillus naganoensis (na.ga.no.en'sis. N.L. gen. n. naganoensis of Nagano, a Japanese Prefecture).

Basonym: Bacillus naganoensis Tomimura et al. 1990.

The description is the same as that given by Tomimura et al., 1990. Additional characteristics found in this study are given above in the genus description.

The type strain is DSM $10191^{\mathrm{T}}\left(=\right.$ ATCC $53909^{\mathrm{T}}=\mathrm{LMG}$ $\left.12887^{\mathrm{T}}\right)$.

\section{Description of Sporolactobacillus laevolacticus comb. nov.}

Sporolactobacillus laevolacticus [lae.vo.lac'ti.cus. N.L. adj. laevolacticus referring to D-(-)-lactic acid, the only lactic acid produced by the organisms].

Basonym: Bacillus laevolacticus Andersch et al. 1994.

The description is the same as that given by Andersch et al., 1994, except for the absence of catalase activity. Additional characteristics found in this study are as follows: cell-wall peptidoglycan contains meso-diaminopimelic acid, alanine, glutamic acid, galactose, mannose and rhamnose.

The type strain is DSM $442^{\mathrm{T}}\left(=\operatorname{ATCC} 23492^{\mathrm{T}}\right)$.

\section{Acknowledgements}

We are grateful to Dr Hiroko Isoda (University of Tsukuba) for kindly permitting us to use a microplate fluorescent reader. This work was supported by a Grant-in-Aid of Open Competition for the Development of Innovative Technology from the Ministry of Education, Culture, Sports, Science and Technology.

\section{References}

Altschul, S. F., Madden, T. L., Schaffer, A. A., Zhang, J., Zhang, Z., Miller, W. \& Lipman, D. J. (1997). Gapped BLAST and PSI-BLAST: a new generation of protein database search programs. Nucleic Acids Res 25, 3389-3402.

Andersch, I., Pianka, S., Fritze, D. \& Claus, D. (1994). Description of Bacillus laevolacticus (ex Nakayama and Yanoshi 1967) sp. nov., nom. rev. Int J Syst Bacteriol 44, 659-664.

Ash, C., Priest, F. G. \& Collins, M. D. (1993). Molecular identification of rRNA group 3 bacilli (Ash, Farrow, Wallbanks and Collins) using a PCR probe test. Proposal for the creation of a new genus Paenibacillus. Antonie van Leeuwenhoek 64, 253-260.

Brosius, J., Palmer, M. L., Kennedy, P. J. \& Noller, H. F. (1978). Complete nucleotide sequence of a $16 \mathrm{~S}$ ribosomal RNA gene from Escherichia coli. Proc Natl Acad Sci U S A 75, 4801-4805.
Claus, D. \& Berkeley, R. C. W. (1986). Genus Bacillus Cohn 1872, $174^{\mathrm{AL}}$. In Bergey's Manual of Systematic Bacteriology, vol. 2, pp. 1105-1139. Edited by P. H. A. Sneath, N. S. Mair, M. E. Sharpe \& J. G. Holt. Baltimore: Williams \& Wilkins.

DeLong, E. F. (1992). Archaea in coastal marine environments. Proc Natl Acad Sci U S A 89, 5685-5689.

Ezaki, T., Hashimoto, Y. \& Yabuuchi, E. (1989). Fluorometric deoxyribonucleic acid-deoxyribonucleic acid hybridization in microdilution wells as an alternative to membrane filter hybridization in which radioisotopes are used to determine genetic relatedness among bacterial strains. Int J Syst Bacteriol 39, 224-229.

Felsenstein, J. (2005). PHYLIP - Phylogeny inference package, version 3.65. Distributed by the author. Department of Genome Sciences, University of Washington, Seattle, USA.

Fogarty, A. M. \& Tuovinen, O. H. (1991). Microbiological degradation of pesticides in yard waste composting. Microbiol Rev 55, 225-233.

Fortina, M. G., Pukall, R., Schumann, P., Mora, D., Parini, C., Manachini, P. L. \& Stackebrandt, E. (2001). Ureibacillus gen. nov., a new genus to accommodate Bacillus thermosphaericus (Andersson et al. 1995), emendation of Ureibacillus thermosphaericus and description of Ureibacillus terrenus sp. nov. Int J Syst Evol Microbiol 51, 447-455.

Goto, K., Omura, T., Hara, Y. \& Sadaie, Y. (2000). Application of the partial $16 \mathrm{~S}$ rDNA sequence as an index for rapid identification of species in the genus Bacillus. J Gen Appl Microbiol 46, 1-8.

Hatayama, K., Kawai, S., Shoun, H., Ueda, Y. \& Nakamura, A. (2005a). Pseudomonas azotifigens sp. nov., a novel nitrogen-fixing bacterium isolated from a compost pile. Int J Syst Evol Microbiol 55, 1539-1544.

Hatayama, K., Shoun, H., Ueda, Y. \& Nakamura, A. (2005b). Planifilum fimeticola gen. nov., sp. nov. and Planifilum fulgidum sp. nov., novel members of the family 'Thermoactinomycetaceae' isolated from compost. Int J Syst Evol Microbiol 55, 2101-2104.

Heyndrickx, M., Lebbe, L., Kersters, K., De Vos, P., Forsyth, G. \& Logan, N. A. (1998). Virgibacillus: a new genus to accommodate Bacillus pantothenticus (Proom and Knight 1950). Emended description of Virgibacillus pantothenticus. Int J Syst Bacteriol 48, 99-106.

Ishii, K., Fukui, M. \& Takii, S. (2000). Microbial succession during a composting process as evaluated by denaturing gradient gel electrophoresis analysis. J Appl Microbiol 89, 768-777.

Kimura, M. (1980). A simple method for estimating evolutionary rates of base substitutions through comparative studies of nucleotide sequences. J Mol Evol 16, 111-120.

Lacey, J. \& Cross, T. (1989). Genus Thermoactinomyces Tsiklinsky $1899,501^{\mathrm{AL}}$. In Bergey's Manual of Systematic Bacteriology, vol. 4, pp. 2574-2585. Edited by S. T. Williams, M. E. Sharpe \& J. G. Holt. Baltimore: Williams \& Wilkins.

Nakayama, O. \& Yanoshi, M. (1967). Spore-bearing lactic acid bacteria isolated from rhizosphere. I. Taxonomic studies on Bacillus laevolacticus nov. sp. and Bacillus racemilacticus nov. sp. J Gen Appl Microbiol 13, 139-153.

Nazina, T. N., Tourova, T. P., Poltaraus, A. B. \& 8 other authors (2001). Taxonomic study of aerobic thermophilic bacilli: descriptions of Geobacillus subterraneus gen. nov., sp. nov. and Geobacillus uzenensis sp. nov. from petroleum reservoirs and transfer of Bacillus stearothermophilus, Bacillus thermocatenulatus, Bacillus thermoleovorans, Bacillus kaustophilus, Bacillus thermoglucosidasius and Bacillus thermodenitrificans to Geobacillus as the new combinations G. stearothermophilus, G. thermocatenulatus, G. thermoleovorans, G. kaustophilus, G. thermoglucosidasius and G. thermodenitrificans. Int J Syst Evol Microbiol 51, 433-446. 
Niimura, Y., Koh, E., Yanagida, F., Suzuki, K.-I., Komagata, K. \& Kozaki, M. (1990). Amphibacillus xylanus gen. nov., sp. nov., a facultatively anaerobic sporeforming xylan-digesting bacterium which lacks cytochrome, quinone, and catalase. Int J Syst Bacteriol 40, 297-301.

Ogino, A., Koshikawa, H., Nakahara, T. \& Uchiyama, H. (2001). Succession of microbial communities during a biostimulation process as evaluated by DGGE and clone library analyses. J Appl Microbiol 91, 625-635.

Page, R. D. M. (1996). TREEVIEW: an application to display phylogenetic trees on personal computers. Comput Appl Biosci 12, 357-358.

Pearson, W. R. (2000). Flexible sequence similarity searching with the FASTA3 program package. Methods Mol Biol 132, 185-219.

Schlesner, H., Lawson, P. A., Collins, M. D., Weiss, N., Wehmeyer, U., Völker, H. \& Thomm, M. (2001). Filobacillus milensis gen. nov., sp. nov., a new halophilic spore-forming bacterium with Orn-D-Glutype peptidoglycan. Int J Syst Evol Microbiol 51, 425-431.

Shida, O., Takagi, H., Kadowaki, K. \& Komagata, K. (1996). Proposal for two new genera, Brevibacillus gen. nov. and Aneurinibacillus gen. nov. Int J Syst Bacteriol 46, 939-946.

Thompson, J. D., Gibson, T. J., Plewniak, F., Jeanmougin, F. \& Higgins, D. G. (1997). The CLUSTAL_X windows interface: flexible strategies for multiple sequence alignment aided by quality analysis tools. Nucleic Acids Res 25, 4876-4882.

Tomimura, E., Zeman, N. W., Frankiewicz, J. R. \& Teague, W. M. (1990). Description of Bacillus naganoensis sp. nov. Int $J$ Syst Bacteriol 40, 123-125.

Wainø, M., Tindall, B. J., Schumann, P. \& Ingvorsen, K. (1999). Gracilibacillus gen. nov., with description of Gracilibacillus halotolerans gen. nov., sp. nov.; transfer of Bacillus dipsosauri to
Gracilibacillus dipsosauri comb. nov., and Bacillus salexigens to the genus Salibacillus gen. nov., as Salibacillus salexigens comb. nov. Int J Syst Bacteriol 49, 821-831.

Williams, R. T., Ziegenfuss, P. S. \& Sisk, W. E. (1992). Composting of explosives and propellant contaminated soils under thermophilic and mesophilic conditions. J Ind Microbiol 9, 137-144.

Wisotzkey, J. D., Jurtshuk, P., Jr, Fox, G. E., Deinhard, G. \& Poralla, K. (1992). Comparative sequence analyses on the $16 \mathrm{~S}$ rRNA (rDNA) of Bacillus acidocaldarius, Bacillus acidoterrestris, and Bacillus cycloheptanicus and proposal for creation of a new genus, Alicyclobacillus gen. nov. Int J Syst Bacteriol 42, 263-269.

Xu, D. \& Côté, J.-C. (2003). Phylogenetic relationships between Bacillus species and related genera inferred from comparison of $3^{\prime}$ end 16S rDNA and $5^{\prime}$ end 16S-23S ITS nucleotide sequences. Int J Syst Evol Microbiol 53, 695-704.

Yanagida, F., Suzuki, K., Kozaki, M. \& Komagata, K. (1997). Proposal of Sporolactobacillus nakayamae subsp. nakayamae sp. nov., subsp. nov., Sporolactobacillus nakayamae subsp. racemicus subsp. nov., Sporolactobacillus terrae sp. nov., Sporolactobacillus kofuensis sp. nov., and Sporolactobacillus lactosus sp. nov. Int J Syst Bacteriol 47, 499-504.

Yoon, J.-H., Weiss, N., Lee, K.-C., Lee, I.-S., Kang, K. H. \& Park, Y.-H. (2001). Jeotgalibacillus alimentarius gen. nov., sp. nov., a novel bacterium isolated from jeotgal with L-lysine in the cell wall, and reclassification of Bacillus marinus Rüger 1983 as Marinibacillus marinus gen. nov., comb. nov. Int J Syst Evol Microbiol 51, 2087-2093.

Zhu, H., Qu, F. \& Zhu, L.-H. (1993). Isolation of genomic DNAs from plants, fungi and bacteria using benzyl chloride. Nucleic Acids Res 21, 5279-5280. 